\title{
Design and Characterization of Gastroretentive Bilayer Tablet of Amoxicillin Trihydrate and Ranitidine Hydrochloride for H. pylori Infection
}

\author{
Shikha Jain, Vikas Jain, S.C. Mahajan \\ Mahakal Institute of Pharmaceutical Studies, Pharmaceutics Gram Datana ujjain, Madhya Pradesh, INDIA
}

\begin{abstract}
Objective: The present study was aimed at developing Gastroretentive Bilayer drug delivery systems containing Amoxicillin Trihydrate and Ranitidine Hydrochloride for the treatment of H. pylori induced peptic ulcer to minimize the side effect, improve the prolongation of action, to reduce the frequency of drug administration. Materials and Method: The tablet is characterized by immediate release layer of Ranitidine Hydrochloride and Gastroretentive layer of Amoxicillin Trihydrate. The formulation containing Gastroretentive layer was designed using HPMC K15M and HPMC K4M as floating agents, sodium bicarbonate and citric acid as gas-generating agent. Crospovidone was used as superdisintegrant for the preparation of immediate release layer. The prepared Gastroretentive layer was evaluated for their precompression parameters, physical characteristics like hardness, friability, uniformity of weight, uniformity of drug content, swelling index, In-vitro floating studies and In-vitro drug release. For the estimation of Ranitidine Hydrochloride and Amoxicillin Trihydrate in a formulation, simultaneous estimation method was employed. Results: The release of the Ranitidine Hydrochloride from the immediate release layer was found to be $94.6 \% \pm 0.02 \%$ in 30 minutes. The release of Amoxicillin Trihydrate for the sustained release floating layer was found to be $90.5 \pm 0.06 \%$ in 12 hours. The data obtained from In-vitro release were fitted into the various kinetic models (Zero Order, Higuchi, First Order and Korsmeyer-Peppas Model). Conclusion: The best fitted model for Amoxicillin Trihydrate and Ranitidine Hydrochloride was found to be zero order release model and first order release model, respectively.
\end{abstract}

Key words: Amoxicillin Trihydrate, bilayer floating tablets, crospovidone, Ranitidine Hydrochloride, superdisintegrant.

\section{INTRODUCTION}

Oral route has been the most widely used and most convenient route for the delivery of drugs. Oral route of administration has received more attention than any other dosage form in the pharmaceutical industry and research field because of the flexibility in designing of dosage form and freedom from problems like sterility and potential damage at the site of administration. Approximately $50 \%$ of the drug delivery system in the market is oral drug delivery system.

Drugs that are rapidly absorbed from the gastrointestinal tract and have a short half life are eliminated quickly from the blood circulation and therefore require frequent dosing. To avoid this problem, the oral sus- tain controlled release formulation have been developed in an attempt to release the drug slowly into the gastrointestinal tract and maintain the therapeutic drug concentration in the serum for longer period of time. The oral controlled-release system is characterized by a typical pattern of drug release in which the drug concentration is maintained in the therapeutic window for a prolonged period of time, thereby ensuring sustained therapeutic action. ${ }^{1}$

Peptic ulcer can be defined as any sore in the linings of GIT particularly stomach or duodenum. There are two most common types of peptic ulcers called "gastric ulcers" and "duodenal ulcers". Peptic ulcer occurs as a result of imbalance between the aggressive
Submission Date : 22-09-14 Revision Date : :11-11-14 AcceptedDate : :01-12-14

DOI: $10.5530 /$ ijper.48.4s.15 Correspondence Address Dr. Vikas jain

Mahakal Institute of Pharmaceutical Studies,

Pharmaceutics Gram Datana ujjain, Madhya Pradesh, INDIA

Telephone: +919617383196

E-mail:vikasjain111180@ gmail.com

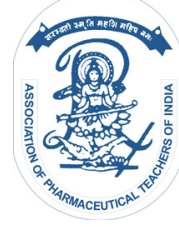

www.ijper.org 
(acid, pepsin, bile and H. pylori) and the defensive (gastric mucus and bicarbonate secretion, prostaglandins, nitric oxide, innate resistance of the mucosal cells) factors. Helicobacter pylori is an important cause of duodenal and gastric ulcers. Greater than $90 \%$ of duodenal ulcers and $70 \%$ of gastric ulcers are associated with $\mathrm{H}$. pylori. H. pylori is a gram-negative, motile, micro-aerophilic, curved bacillus that is found in the mucus layer overlying the gastric epithelium. ${ }^{2}$

The treatment for eradication of $\mathrm{H}$. pylori is complicated, requiring a combination of an antibiotic with gastric acid inhibitors. Therefore, a well designed drug delivery system is required to overcome the troubles of conventional therapy and to enhance the therapeutic efficacy of given drug regimens.

Gastroretentive drug deliveries locate the drug within the stomach and prolong ultimate contact with the absorbing membrane and increases efficacy. This is particularly important in the treatment of microorganisms which colonize in the stomach because the three main fraction reducing luminal delivery of drug to them are gastric emptying, gastric acidity and epithelial mucus layer. In particular, H. Pylori lives deep within the gastric mucus layer and prolonged local application is needed for sufficient to diffuse to the bacteria.

The current investigation aims at the development of Gastroretentive Bilayer floating tablets with different release patterns of amoxicillin and ranitidine. Amoxicillin Trihydrate is an antibiotic to treat H. Pylori and Ranitidine Hydrochloride is an antacid to reduce gastric acid secretion.

\section{MATERIALS AND METHOD}

Amoxicillin and ranitidine were obtained as a gift sample form Ranbaxy Laboratories Ltd. Dewas, M.P. HPMC K4M and HPMC K15M were purchased from Colorcon Asia Pvt Ltd, Mumbai; Citric acid was purchased from Qualigens Fine Chemicals; Sodium bicarbonate was purchased from Rankem Laboratories; Lactose monohydrate, Magnesium stearate were purchased from S.D. Fine Chemicals Pvt. Ltd. All other chemicals were of analytical grades.

\section{Preparation of Gastroretentive Bilayer tablet}

Gastroretentive Bilayer tablets consisting of bottom floating layer as bottom and immediate release layer as top layer were prepared in two stages as following: ${ }^{3}$

- Preparation of ranitidine immediate release layer

- Preparation of amoxicillin sustained release layer

\section{Preparation of Ranitidine immediate release layer}

Ranitidine immediate release layer were prepared by taking variable concentration of crospovidone and microcrystalline cellulose at three levels. Ranitidine immediate release layer were prepared by using direct compression method. Ranitidine was weighed and passed (sieve) through mesh no. 40. Crospovidone, microcrystalline cellulose, and lactose were passed (sieve) through mesh no. 60. The active ingredient, Crospovidone, microcrystalline cellulose and lactose were mixed in a poly bag for 5 minutes. Magnesium stearate previously passed through mesh no. 60 was mixed well in a poly bag for 3 minutes. The blend was directly compressed using single punch tablet compression machine. The composition of ranitidine tablet layer is shown in Table 1.

\section{Preparation of Amoxicillin sustained release layer}

Sustained release layers of Amoxicillin were prepared using experimental design by varying the concentration of HPMCK4M, HPMCK15M and carbopol P-940 by direct compression method. Amoxicillin was weighed and passed (sieve) through mesh no. 40. HPMC, Carbopol, sodium bicarbonate, citric acid, lactose were weighed and passed (sieve) through mesh no. 60. The

Table 1: Composition of RAN tablet layer

\begin{tabular}{|c|c|c|c|c|c|c|c|c|c|}
\hline \multirow{2}{*}{ Ingredients } & \multicolumn{9}{|c|}{ Formulation code } \\
\hline & R1 & R2 & R3 & R4 & R5 & R6 & R7 & R8 & R9 \\
\hline $\begin{array}{l}\text { Ranitidine } \\
\text { Hydrochloride }\end{array}$ & 100 & 100 & 100 & 100 & 100 & 100 & 100 & 100 & 100 \\
\hline $\begin{array}{l}\text { Cross Povidone } \\
(2-6 \%)\end{array}$ & $\begin{array}{c}3 \\
(2 \%)\end{array}$ & $\begin{array}{c}3 \\
(2 \%)\end{array}$ & $\begin{array}{c}3 \\
(2 \%)\end{array}$ & $\begin{array}{c}6 \\
(4 \%)\end{array}$ & $\begin{array}{c}6 \\
(4 \%)\end{array}$ & $\begin{array}{c}6 \\
(4 \%)\end{array}$ & $\begin{array}{c}9 \\
(6 \%)\end{array}$ & $\begin{array}{c}9 \\
(6 \%)\end{array}$ & $\begin{array}{c}9 \\
(6 \%)\end{array}$ \\
\hline $\begin{array}{l}\text { Microcrystalline } \\
\text { cellulose }\end{array}$ & 0 & 15 & 30 & 0 & 15 & 30 & 0 & 15 & 30 \\
\hline Lactose & 39.5 & 24.5 & 9.5 & 36.5 & 21.5 & 6.5 & 33.5 & 18.5 & 3.5 \\
\hline $\begin{array}{l}\text { Magnesium } \\
\text { stearate }\end{array}$ & 7.5 & 7.5 & 7.5 & 7.5 & 7.5 & 7.5 & 7.5 & 7.5 & 7.5 \\
\hline Total & 150 & 150 & 150 & 150 & 150 & 150 & 150 & 150 & 150 \\
\hline
\end{tabular}


Table 2: Composition of AMOX tablet layer

\begin{tabular}{|c|c|c|c|c|c|c|c|c|c|c|c|c|}
\hline \multirow[t]{2}{*}{ Ingredients } & \multicolumn{12}{|c|}{ Formulation code } \\
\hline & A1 & A2 & A3 & A4 & A5 & A6 & A7 & A8 & A9 & A10 & A11 & A12 \\
\hline $\begin{array}{l}\text { Amoxicillin } \\
\text { Trihydrate }\end{array}$ & 250 & 250 & 250 & 250 & 250 & 250 & 250 & 250 & 250 & 250 & 250 & 250 \\
\hline $\begin{array}{l}\text { HPMCK4M } \\
(10-30 \%)\end{array}$ & 45 & 90 & 135 & - & - & - & - & - & - & 67.5 & - & 67.5 \\
\hline $\begin{array}{l}\text { HPMCK15M } \\
(10-30 \%)\end{array}$ & - & - & - & 45 & 90 & 135 & - & - & - & 67.5 & 67.5 & - \\
\hline $\begin{array}{c}\text { Carbopol P 940(10- } \\
30 \%)\end{array}$ & - & - & - & - & - & - & 45 & 90 & 135 & - & 67.5 & 67.5 \\
\hline Sodium bicarbonate & 36 & 36 & 36 & 36 & 36 & 36 & 36 & 36 & 36 & 36 & 36 & 36 \\
\hline Citric acid & 9 & 9 & 9 & 9 & 9 & 9 & 9 & 9 & 9 & 9 & 9 & 9 \\
\hline Magnesium stearate & 11.5 & 11.5 & 11.5 & 11.5 & 11.5 & 11.5 & 11.5 & 11.5 & 11.5 & 11.5 & 11.5 & 11.5 \\
\hline Lactose & 98.5 & 53.5 & 8.5 & 98.5 & 53.5 & 8.5 & 98.5 & 53.5 & 8.5 & 98.5 & 53.5 & 8.5 \\
\hline Total & 450 & 450 & 450 & 450 & 450 & 450 & 450 & 450 & 450 & 450 & 450 & 450 \\
\hline
\end{tabular}

active ingredient, HPMC, Carbopol, sodium bicarbonate, citric acid, lactose were mixed in a poly bag for 5 minutes. Magnesium stearate previously passed through mesh no. 60 was mixed well in a poly bag for 3 minutes. The blend was directly compressed using single punch tablet compression machine. The composition of AMOX tablet layer is shown in Table 2.

\section{Fabrication of Gastroretentive Bilayer tablet}

As the upper punch was raised the immediate release layer of ranitidine was placed on the above the sustained release layer of amoxicillin; the 2 layers were then compressed into a floating bilayer tablet. Each tablet weighed $600 \mathrm{mg}$ containing $100 \mathrm{mg}$ ranitidine and $250 \mathrm{mg}$ amoxicillin. Bilayer tablet containing ranitidine hydrochloride (upper layer) and amoxicillin trihydrate (bottom layer) is presented in Figure 1.

\section{Evaluation of tablet}

\section{Pre-compression parameters of powder blend}

The prepared powder blend was evaluated for parameters like bulk density, tapped density, Carr's index, Angle of repose, and Hausner's ratio. The pre-compression parameters of powder blend of both the layers are reported in Table 3 and Table 4.

\section{Post-compression parameters}

\section{Hardness}

Hardness indicated the ability of the tablet to withstand mechanical shocks while handling. The hardness of the tablet layers were determined using Monsanto hardness tester. Three tablets form each formulation was randomly picked and hardness of the tablets was determined. The hardness of RAN tablet layer and AMOX

\begin{tabular}{|c|c|c|c|c|c|}
\hline \multirow[b]{2}{*}{ Formulation code } & \multicolumn{5}{|c|}{ Parameters } \\
\hline & $\begin{array}{l}\text { Bulk density } \\
\left(\mathrm{g} / \mathrm{cm}^{3}\right)\end{array}$ & $\begin{array}{c}\text { Tapped density (g/ } \\
\left.\mathrm{cm}^{3}\right)\end{array}$ & Angle of repose $\left({ }^{\circ}\right)$ & Hausner's Ratio & $\begin{array}{c}\text { Carr's } \\
\text { compressibility } \\
\text { index (\%) }\end{array}$ \\
\hline R1 & $0.476 \pm 0.013$ & $0.563 \pm 0.025$ & $25.18 \pm 0.11$ & $1.18 \pm 0.019$ & $15.4 \pm 0.023$ \\
\hline R2 & $0.455 \pm 0.029$ & $0.567 \pm 0.023$ & $26.18 \pm 0.16$ & $1.24 \pm 0.026$ & $19.7 \pm 0.019$ \\
\hline R3 & $0.463 \pm 0.014$ & $0.536 \pm 0.024$ & $27.86 \pm 0.14$ & $1.15 \pm 0.019$ & $13.6 \pm 0.015$ \\
\hline R4 & $0.455 \pm 0.014$ & $0.583 \pm 0.023$ & $28.54 \pm 0.13$ & $1.25 \pm 0.018$ & $21.9 \pm 0.014$ \\
\hline R5 & $0.474 \pm 0.013$ & $0.551 \pm 0.027$ & $29.37 \pm 0.15$ & $1.16 \pm 0.02$ & $13.9 \pm 0.017$ \\
\hline R6 & $0.478 \pm 0.019$ & $0.557 \pm 0.023$ & $28.68 \pm 0.17$ & $1.16 \pm 0.021$ & $14.1 \pm 0.018$ \\
\hline R7 & $0.449 \pm 0.017$ & $0.558 \pm 0.027$ & $29.56 \pm 0.12$ & $1.24 \pm 0.022$ & $19.5 \pm 0.015$ \\
\hline R8 & $0.455 \pm 0.018$ & $0.551 \pm 0.026$ & $28.72 \pm 0.16$ & $1.21 \pm 0.022$ & $17.4 \pm 0.023$ \\
\hline R9 & $0.465 \pm 0.014$ & $0.559 \pm 0.024$ & $28.31 \pm 0.18$ & $1.20 \pm 0.021$ & $16.8 \pm 0.019$ \\
\hline
\end{tabular}




\section{Table 4: Pre-compression parameters of powder blend for AMOX tablet layer}

\begin{tabular}{|c|c|c|c|c|c|}
\hline \multirow[b]{2}{*}{ Formulation code } & \multicolumn{5}{|c|}{ Parameters } \\
\hline & $\begin{array}{l}\text { Bulk density } \\
\left(\mathrm{g} / \mathrm{cm}^{3}\right)\end{array}$ & $\begin{array}{l}\text { Tapped density } \\
\qquad\left(\mathrm{g} / \mathrm{cm}^{3}\right)\end{array}$ & Angle of repose $\left(^{\circ}\right)$ & Hausner's Ratio & $\begin{array}{c}\text { Carr's } \\
\text { compressibility } \\
\text { index }(\%)\end{array}$ \\
\hline A1 & $0.466 \pm 0.013$ & $0.573 \pm 0.027$ & $24 \pm 0.16$ & $1.22 \pm 0.02$ & $18.6 \pm 0.014$ \\
\hline A2 & $0.457 \pm 0.017$ & $0.577 \pm 0.026$ & $26 \pm 0.13$ & $1.26 \pm 0.021$ & $20.7 \pm 0.011$ \\
\hline A3 & $0.474 \pm 0.014$ & $0.580 \pm 0.023$ & $25 \pm 0.17$ & $1.22 \pm 0.018$ & $18.2 \pm 0.012$ \\
\hline A4 & $0.465 \pm 0.012$ & $0.583 \pm 0.023$ & $27 \pm 0.15$ & $1.25 \pm 0.017$ & $20.2 \pm 0.017$ \\
\hline A5 & $0.474 \pm 0.011$ & $0.565 \pm 0.026$ & $28 \pm 0.14$ & $1.19 \pm 0.018$ & $16.1 \pm 0.013$ \\
\hline A6 & $0.481 \pm 0.015$ & $0.567 \pm 0.021$ & $25 \pm 0.12$ & $1.17 \pm 0.018$ & $15.1 \pm 0.014$ \\
\hline A7 & $0.459 \pm 0.017$ & $0.568 \pm 0.025$ & $27 \pm 0.15$ & $1.23 \pm 0.021$ & $19.1 \pm 0.011$ \\
\hline A8 & $0.460 \pm 0.013$ & $0.576 \pm 0.023$ & $26 \pm 0.13$ & $1.25 \pm 0.018$ & $20.1 \pm 0.015$ \\
\hline A9 & $0.471 \pm 0.014$ & $0.579 \pm 0.022$ & $28 \pm 0.14$ & $1.22 \pm 0.018$ & $18.6 \pm 0.012$ \\
\hline A10 & $0.464 \pm 0.011$ & $0.548 \pm 0.021$ & $25 \pm 0.16$ & $1.18 \pm 0.016$ & $15.3 \pm 0.017$ \\
\hline A11 & $0.477 \pm 0.015$ & $0.576 \pm 0.022$ & $24 \pm 0.12$ & $1.2 \pm 0.018$ & $17.1 \pm 0.013$ \\
\hline A12 & $0.461 \pm 0.017$ & $0.581 \pm 0.024$ & $26 \pm 0.17$ & $1.25 \pm 0.020$ & $20.6 \pm 0.015$ \\
\hline
\end{tabular}

Table 5: Optimization parameters for RAN tablet layer

\begin{tabular}{|l|c|c|c|c|c|c|}
\hline \multirow{2}{*}{$\begin{array}{l}\text { Formulation } \\
\text { code }\end{array}$} & $\begin{array}{c}\text { Hardness (Kg/ } \\
\mathbf{c m}^{\mathbf{2}} \mathbf{)}\end{array}$ & $\begin{array}{c}\text { Friability } \\
\mathbf{( \% )}\end{array}$ & $\begin{array}{c}\text { Uniformity of } \\
\text { weight (\%) }\end{array}$ & $\begin{array}{c}\text { Disintegration time } \\
\text { (Second) }\end{array}$ & $\begin{array}{c}\text { In-vitro } \\
\text { dispersion time } \\
\text { (Minutes) }\end{array}$ & $\begin{array}{c}\text { Drug content } \\
\text { (\%) }\end{array}$ \\
\hline R1 & $4.1 \pm 1.2$ & 0.561 & $1.32 \pm 0.06$ & $25 \pm 1.1$ & $45 \pm 1.2$ & 98.65 \\
\hline R2 & $4.5 \pm 1.4$ & 0.490 & $1.42 \pm 0.08$ & $23 \pm 1.2$ & $42 \pm 1.1$ & 97.79 \\
\hline R3 & $4.3 \pm 1.5$ & 0.662 & $1.65 \pm 0.05$ & $25 \pm 0.95$ & $44 \pm 1.4$ & 99.34 \\
\hline R4 & $4.2 \pm 1.9$ & 0.451 & $1.28 \pm 0.07$ & $25 \pm 1.2$ & $48 \pm 1.3$ & 98.74 \\
\hline R5 & $4.1 \pm 1.4$ & 0.565 & $1.30 \pm 0.04$ & $24 \pm 1.1$ & $31 \pm 1.1$ & 98.96 \\
\hline R6 & $4.2 \pm 1.2$ & 0.586 & $1.82 \pm 0.06$ & $25 \pm 1.2$ & $33 \pm 0.98$ & 99.39 \\
\hline R7 & $4.1 \pm 1.5$ & 0.481 & $1.95 \pm 0.04$ & $24 \pm 1.1$ & $35 \pm 1.2$ & 98.28 \\
\hline R8 & $4.1 \pm 1.8$ & 0.560 & $1.34 \pm 0.08$ & $23 \pm 1.2$ & $33 \pm 1.4$ & 99.16 \\
\hline R9 & $4.5 \pm 1.2$ & 0.465 & $1.30 \pm 0.09$ & $22 \pm 1.2$ & $31 \pm 1.2$ & 98.89 \\
\hline Where all values are mean S.D. for n=3 & & & & & \\
\hline
\end{tabular}

Table 6: Optimization parameters of AMOX tablet layer

\begin{tabular}{|c|c|c|c|c|c|c|c|}
\hline \multirow[b]{2}{*}{$\begin{array}{l}\text { Formulation } \\
\text { code }\end{array}$} & \multicolumn{7}{|c|}{ Parameters } \\
\hline & $\begin{array}{l}\text { Hardness } \\
\left(\mathrm{Kg} / \mathrm{cm}^{2}\right)\end{array}$ & Friability (\%) & $\begin{array}{c}\text { Uniformity of } \\
\text { weight (\%) }\end{array}$ & $\begin{array}{c}\text { Swelling } \\
\text { index in } 1 \\
\text { hour (\%) }\end{array}$ & $\begin{array}{l}\text { Buoyancy } \\
\text { lag time } \\
\text { (Minutes) }\end{array}$ & $\begin{array}{c}\text { Duration } \\
\text { of Floating } \\
\text { (hours) }\end{array}$ & $\begin{array}{c}\text { Drug content } \\
(\%)\end{array}$ \\
\hline A1 & $4.1 \pm 0.67$ & 0.93 & $1.27 \pm 0.08$ & 12.2 & $1.1 \pm 0.90$ & $>8$ & 97.3 \\
\hline A2 & $4.4 \pm 0.51$ & 0.89 & $1.56 \pm 0.09$ & 12.7 & $1.3 \pm 0.87$ & $>8$ & 94.5 \\
\hline A3 & $4.3 \pm 0.33$ & 0.86 & $1.45 \pm 0.09$ & 13.1 & $1.45 \pm 0.94$ & $>8$ & 95.7 \\
\hline A4 & $4.6 \pm 0.17$ & 0.91 & $1.53 \pm 0.06$ & 13.4 & $1.27 \pm 0.79$ & $>8$ & 98.4 \\
\hline A5 & $4.7 \pm 0.20$ & 0.90 & $1.37 \pm 0.07$ & 13.5 & $1.43 \pm 0.68$ & $>8$ & 96.3 \\
\hline A6 & $4.6 \pm 0.28$ & 0.88 & $1.63 \pm 0.05$ & 13.2 & $1.38 \pm 0.88$ & $>8$ & 98.1 \\
\hline A7 & $4.1 \pm 0.65$ & 0.89 & $1.71 \pm 0.07$ & 12.5 & $1.36 \pm 0.91$ & $>8$ & 97.84 \\
\hline A8 & $4.6 \pm 0.45$ & 0.96 & $1.66 \pm 0.05$ & 12.7 & $1.41 \pm 0.85$ & $>8$ & 96.58 \\
\hline A9 & $4.7 \pm 0.35$ & 0.87 & $1.59 \pm 0.08$ & 12.3 & $1.46 \pm 0.84$ & $>8$ & 98.71 \\
\hline A10 & $4.2 \pm 0.78$ & 0.91 & $1.61 \pm 0.06$ & 12.8 & $1.43 \pm 0.77$ & $>8$ & 97.47 \\
\hline A11 & $4.6 \pm 0.65$ & 0.93 & $1.78 \pm 0.05$ & 12.6 & $1.37 \pm 0.92$ & $>8$ & 96.68 \\
\hline A12 & $4.4 \pm 0.40$ & 0.89 & $1.65 \pm 0.07$ & 12.5 & $1.41 \pm 0.81$ & $>8$ & 95.62 \\
\hline
\end{tabular}


Table 7: Evaluation parameters of optimized bilayer tablet

\begin{tabular}{|l|c|}
\hline Parameter & Observations \\
\hline Hardness (Kg/cm $\mathbf{~})$ & $4.4 \pm 0.35$ \\
\hline Friability (\%) & 0.642 \\
\hline Weight variation (\%) & $1.30 \pm 0.04$ \\
\hline $\begin{array}{l}\text { Drug content (mg) } \\
\text {-Ranitidine } \\
\text {-Amoxicillin }\end{array}$ & 98.4 \\
\hline Disintegration time (Seconds) & 248.6 \\
\hline In-vitro dispersion time (Seconds) & $25 \pm 1.2$ \\
\hline Buoyancy lag time (Minutes) & $37 \pm 1.2$ \\
\hline Duration of floating (Hours) & $1.57 \pm 0.83$ \\
\hline Swelling index (\%) & $>8$ \\
\hline
\end{tabular}

tablet layer are shown in Table 5 and 6 respectively. The hardness of optimized bilayer tablet is reported in Table 7.

\section{Friability test ${ }^{4}$}

The friability of tablets was determined using Roche friabilator. Ten tablets were initially weighed $\left(\mathrm{W}_{\text {Initial }}\right)$ and placed into friabilator. The friabilator as operated at 25 rpm for 4 minutes i.e. 100 revolutions. The tablets were then taken out, dusted and then weighed again $\left(\mathrm{W}_{\text {Final }}\right)$. The $\%$ friability was calculated by using formula:

$\% \mathrm{~F}=100\left(1-\mathrm{W}_{\text {Final }} / \mathrm{W}_{\text {Initial }}\right)$

The values of friability of RAN tablet layer and AMOX tablet layer are shown in Table 5 and 6 respectively. The friability of optimized bilayer tablet is reported in Table 7 .

\section{Uniformity of weight ${ }^{5}$}

Twenty tablets were randomly selected from each batch individually weighed, the average weight and standard deviation of 20 tablets was calculated. The data of weight variation test of RAN tablet layer and AMOX tablet layer are shown in Table 5 and 6 respectively. The

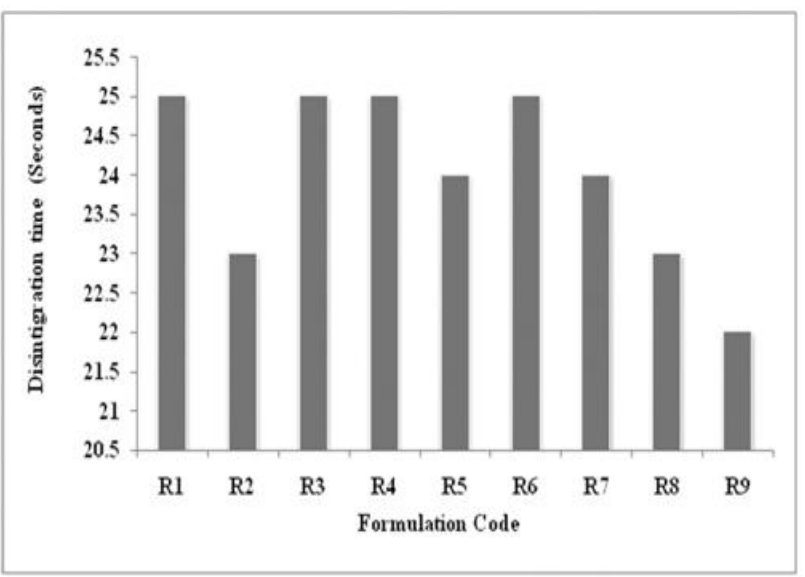

Figure 2: Disintegration time of RAN tablet layer

data of weight variation test of optimized bilayer tablet is reported in Table 7.

\section{Disintegration test}

Disintegration test is performed to ensure that the drug substance is fully available for dissolution and absorption from the gastrointestinal tract. One tablet was placed in each tube and the basket rack was positioned in a $1 \mathrm{~L}$ beaker of simulated gastric fluid at $37 \pm 2{ }^{\circ} \mathrm{C}$, such that tablet remains $2.5 \mathrm{~cm}$ below the surface of the liquid on their upward movement and descends not closer than $2.5 \mathrm{~cm}$. from the bottom of the beaker. A standard motor driven device was used to move the basket assembly containing the tablets up and down through a distance of (5 to 6) $\mathrm{cm}$. at the frequency of 28-32 cycles per minute. Time at which there is no fraction of tablet present in the tube was noted. The disintegration time of RAN tablet layer is reported in Table 5. The disintegration time plot obtained for the RAN tablet layer is shown in Figure 2. The disintegration time of optimized bilayer tablet is reported in Table 7 .

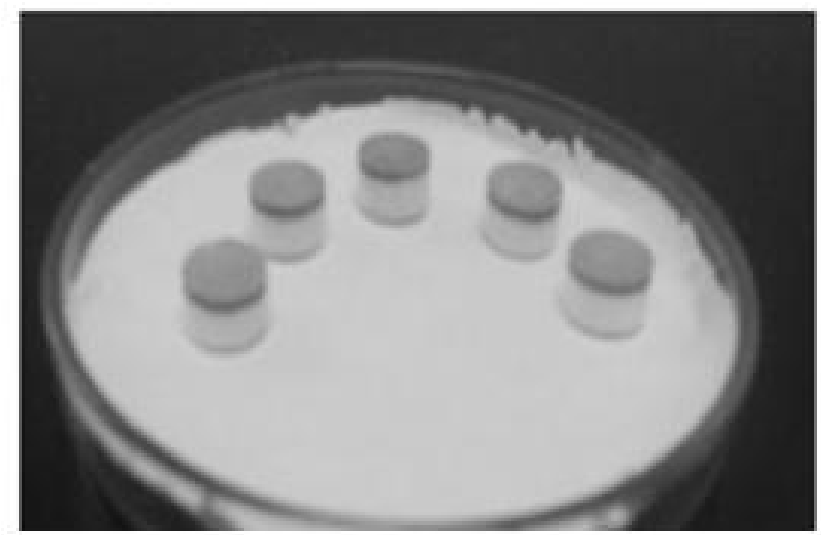

Figure 1: Bilayer tablet containing ranitidine hydrochloride (upper layer) and amoxicillin trihydrate (bottom layer)

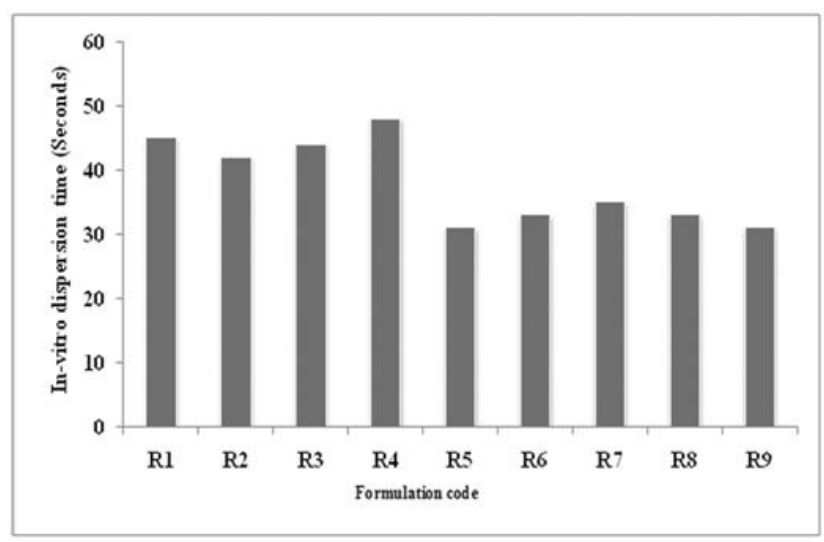

Figure 3: In vitro dispersion time of RAN tablet layer 


\section{In-vitro dispersion time}

In-vitro dispersion time was determined by dropping a tablet into a $10 \mathrm{ml}$ measuring cylinder containing 10 $\mathrm{ml}$ of $\mathrm{pH} 1.2$ buffer. The total duration of time taken by the tablet to completely disperse in the buffer was noted. The In-vitro dispersion time of RAN tablet layer are shown in Table 5. The In-vitro dispersion time plot obtained for the RAN tablet layer is shown in Figure 3.

\section{Drug content}

\section{Determination of drug content in RAN layer ${ }^{7}$}

Twenty tablets were weighed and grounded into a fine powder. An amount of powder equivalent to $200 \mathrm{mg}$ of ranitidine $\mathrm{HCl}$ was weighed accurately and mixed with $70 \mathrm{ml}$ of distilled water in a $100 \mathrm{ml}$ volumetric flask. The mixture was shaken for about 20 minutes. Volume was made upto $100 \mathrm{ml}$ with distilled water and filtered. Filtrate equivalent to $2 \mathrm{mg} / \mathrm{ml}$ was diluted appropriately to obtain a $100 \mu \mathrm{g} / \mathrm{ml}$ solution which is then analyzed by UV-spectrophotometry.

\section{Determination of drug content in AMOX layer}

Ten tablets were weighed and triturated to get the powder. Weight equivalent to $100 \mathrm{mg}$ of AMOX was dissolved in $50 \mathrm{ml}$ of distilled water and sonicated for 15 minutes. The volume was adjusted to $100 \mathrm{ml}$ using distilled water and filtered. $2 \mathrm{ml}$ of this solution was diluted to $10 \mathrm{ml}$ with distilled water and analyzed at $230 \mathrm{~nm}$ using UV-spectrophotometry.

\section{Simultaneous estimation of ranitidine and amoxicillin in bilayer tablet ${ }^{8}$}

Powder equivalent to $100 \mathrm{mg}$ of Ranitidine Hydrochloride and $250 \mathrm{mg}$ of Amoxicillin Trihydrate was weighed accurately and transferred to $1000 \mathrm{ml}$ volumetric flask. Sufficient quantity of distilled water was added to dissolve the drugs completely. Volume was adjusted to $1000 \mathrm{ml}$ with distilled water. $1 \mathrm{ml}$ of this solution was diluted to $10 \mathrm{ml}$ with distilled water. Absorbance of the resulting solution was measured at (228 and 313) $\mathrm{nm}$. Concentration was determined by UV-spectrophotometry by simultaneous estimation method.

The values of drug content of RAN tablet layer and AMOX tablet layer are shown in Table 5 and 6 respectively. The drug content of optimized bilayer tablet is reported in Table 7.

\section{Floating parameters}

\section{Buoyancy lag time ${ }^{9}$}

The buoyancy of tablets was studied at $37 \pm 0.5^{\circ} \mathrm{C}$ in $100 \mathrm{ml}$ of $0.1 \mathrm{~N} \mathrm{HCl}$. A glass beaker containing $100 \mathrm{ml}$ of $0.1 \mathrm{~N} \mathrm{HCl}$ was taken, in which AMOX tablet layer was placed for observation. The duration of time taken by the tablet to float was observed visually. The data for the buoyancy lag time study of AMOX tablet layers are shown in Table 6 . The buoyancy lag time of optimized bilayer tablet is reported in Table 7. Buoyancy lag time of AMOX tablet layer and Buoyancy study at different time intervals are presented in Figure $4 \& 5$.

\section{Duration of floating time}

A glass beaker containing $100 \mathrm{ml}$ of $0.1 \mathrm{~N} \mathrm{HCl}$ was taken, in which AMOX tablet layer was placed for observation. The total duration for which tablet remains floating was recorded as duration of floatation. The data of the floating time study of AMOX tablet layers are shown in Table 6. The floating duration of optimized bilayer tablet id reported in Table 7.

\section{Swelling index ${ }^{10}$}

The swelling properties of tablet layer containing AMOX were determined by placing the tablet in the USP Dissolution Testing Apparatus II, in $900 \mathrm{ml}$ of 0.1 $\mathrm{N} \mathrm{HCl}$ at $37 \pm 0.5{ }^{\circ} \mathrm{C}$, rotated at $50 \mathrm{rpm}$ for $30 \mathrm{~min}-$ utes. The tablets were removed then from dissolution medium, blotted to remove excess water and weighed. Swelling characteristics were expressed in terms of percentage water uptake (WU \%) according to the equation.

$$
\text { Swelling Index }=(\mathrm{Wt}-\mathrm{Wo}) * 100 / \mathrm{W}
$$

Where, Wt $=$ Weight of dry tablet, Wo= Weight of swollen tablet

The swelling index of AMOX tablet layers are shown in Table 6. The swelling index of optimized bilayer tablet is reported in Table 7 .

\section{In-vitro dissolution studies}

The optimized formulated tablet layer beds of both the drugs were subjected to in-vitro dissolution study. Invitro dissolution of RAN and AMOX was performed using $900 \mathrm{ml}$ of $\mathrm{pH} 1.2$ buffer as the dissolution media at $75 \mathrm{rpm}$ using USP apparatus II. $5 \mathrm{ml}$ sample was withdrawn and replaced with the fresh dissolution media at regular time intervals. The samples were subsequently diluted and filtered. The concentrations of RAN and AMOX in samples were determined by UV-spectrophotometry.

The release profiles obtained for the formulations R1-R5 and R6-R9 are presented in Table 8 and 9 respectively. The release profiles obtained for the formulations A1-A6 and A7-A12 are presented in Table 10 and 11 respectively. The release profile of optimized bilayer tablet is presented in Table 12. The release plots obtained for the formulations are shown in Figure 6 (R1-R3), 7 (R4-R6), 8 (R7-R9), 9 (A1-A3), 10 (A4-A6), 


\begin{tabular}{|c|c|c|c|c|c|}
\hline \multirow[t]{2}{*}{ Time (Minutes) } & \multicolumn{5}{|c|}{$\%$ drug release in $0.1 \mathrm{~N} \mathrm{HCl}$} \\
\hline & R1 & $\mathbf{R 2}$ & R3 & R4 & R5 \\
\hline 0 & $0.00 \pm 00$ & $0.00 \pm 00$ & $0.00 \pm 00$ & $0.00 \pm 00$ & $0.00 \pm 00$ \\
\hline 5 & $13.7 \pm 0.04$ & $15.1 \pm 0.06$ & $12.5 \pm 0.03$ & $13.4 \pm 0.03$ & $15.0 \pm 0.05$ \\
\hline 10 & $25.5 \pm 0.07$ & $29.4 \pm 0.05$ & $28.0 \pm 0.04$ & $24.7 \pm 0.05$ & $27.5 \pm 0.03$ \\
\hline 15 & $39.6 \pm 0.05$ & $45.2 \pm 0.02$ & $41.7 \pm 0.06$ & $35.1 \pm 0.02$ & $40.6 \pm 0.05$ \\
\hline 20 & $58.1 \pm 0.05$ & $63.4 \pm 0.5$ & $62.2 \pm 0.03$ & $53.2 \pm 0.04$ & $60.5 \pm 0.03$ \\
\hline 25 & $73.7 \pm 0.04$ & $77.1 \pm 0.03$ & $74.2 \pm 0.06$ & $65.5 \pm 0.05$ & $77.1 \pm 0.06$ \\
\hline 30 & $84.2 \pm 0.03$ & $87.6 \pm 0.02$ & $92.2 \pm 0.03$ & $82.2 \pm 0.03$ & $87.4 \pm 0.04$ \\
\hline
\end{tabular}

\begin{tabular}{|c|c|c|c|c|}
\hline \multirow{2}{*}{$\begin{array}{l}\text { Time } \\
\text { (Minutes) }\end{array}$} & \multicolumn{4}{|c|}{$\%$ drug release in $0.1 \mathrm{~N} \mathrm{HCl}$} \\
\hline & R6 & R7 & $\mathbf{R 8}$ & $\mathbf{R 9}$ \\
\hline 0 & $0.00 \pm 0.00$ & $0.00 \pm 0.00$ & $0.00 \pm 0.00$ & $0.00 \pm 0.00$ \\
\hline 5 & $17.6 \pm 0.05$ & $12.4 \pm 0.03$ & $15.7 \pm 0.04$ & $14.5 \pm 0.03$ \\
\hline 10 & $30.0 \pm 0.07$ & $25.7 \pm 0.05$ & $30.1 \pm 0.02$ & $27.6 \pm 0.03$ \\
\hline 15 & $45.1 \pm 0.02$ & $44.7 \pm 0.02$ & $45.5 \pm 0.07$ & $40.5 \pm 0.07$ \\
\hline 20 & $63.5 \pm 0.04$ & $60.8 \pm 0.02$ & $66.1 \pm 0.03$ & $58.2 \pm 0.05$ \\
\hline 25 & $79.8 \pm 0.05$ & $75.6 \pm 0.04$ & $80.0 \pm 0.02$ & $70.5 \pm 0.04$ \\
\hline 30 & $92.8 \pm 0.06$ & $90.1 \pm 0.08$ & $94.2 \pm 0.05$ & $87.6 \pm 0.03$ \\
\hline
\end{tabular}

\begin{tabular}{|c|c|c|c|c|c|c|}
\hline \multirow[t]{2}{*}{ Time (Hour) } & \multicolumn{6}{|c|}{$\%$ drug release in $0.1 \mathrm{~N} \mathrm{HCl}$} \\
\hline & A1 & A2 & A3 & A4 & A5 & A6 \\
\hline 0 & $0.00 \pm 00$ & $0.00 \pm 00$ & $0.00 \pm 00$ & $0.00 \pm 00$ & $0.00 \pm 00$ & $0.00 \pm 00$ \\
\hline 1 & $8.2 \pm 0.02$ & $10.6 \pm 0.03$ & $12.5 \pm 0.05$ & $11.4 \pm 0.05$ & $12.3 \pm 0.03$ & $11.7 \pm 0.05$ \\
\hline 2 & $16.4 \pm 0.06$ & $18.1 \pm 0.03$ & $20.4 \pm 0.02$ & $18.8 \pm 0.02$ & $18.7 \pm 0.05$ & $17.9 \pm 0.02$ \\
\hline 3 & $21.1 \pm 0.04$ & $23.7 \pm 0.04$ & $26.2 \pm 0.03$ & $24.5 \pm 0.04$ & $26.4 \pm 0.02$ & $25.9 \pm 0.04$ \\
\hline 4 & $29.2 \pm 0.02$ & $31.4 \pm 0.02$ & $33.7 \pm 0.02$ & $32.1 \pm 0.04$ & $32.7 \pm 0.04$ & $31.9 \pm 0.06$ \\
\hline 5 & $35.5 \pm 0.05$ & $38.5 \pm 0.04$ & $40.1 \pm 0.06$ & $39.2 \pm 0.03$ & $40.8 \pm 0.06$ & $39.8 \pm 0.06$ \\
\hline 6 & $41.7 \pm 0.03$ & $43.2 \pm 0.05$ & $46.4 \pm 0.03$ & $45.0 \pm 0.03$ & $47.1 \pm 0.04$ & $47.4 \pm 0.03$ \\
\hline 7 & $48.0 \pm 0.04$ & $50.6 \pm 0.04$ & $53.1 \pm 0.04$ & $51.5 \pm 0.05$ & $53.2 \pm 0.02$ & $54.1 \pm 0.04$ \\
\hline 8 & $56.1 \pm 0.04$ & $59.5 \pm 0.02$ & $61.1 \pm 0.04$ & $58.7 \pm 0.02$ & $59.1 \pm 0.03$ & $60.5 \pm 0.05$ \\
\hline 9 & $62.5 \pm 0.02$ & $65.4 \pm 0.05$ & $67.7 \pm 0.03$ & $65.8 \pm 0.03$ & $66.2 \pm 0.03$ & $67.1 \pm 0.03$ \\
\hline 10 & $70.2 \pm 0.05$ & $72.1 \pm 0.03$ & $75.0 \pm 0.04$ & $72.9 \pm 0.04$ & $74.5 \pm 0.02$ & $75.2 \pm 0.04$ \\
\hline
\end{tabular}

11 (A7-A9), 12 (A10-12). The release plot obtained for the optimized bilayer tablet is shown in Figure 13.

\section{Kinetics of drug release ${ }^{11}$}

To determine the drug release mechanism, the in-vitro release data was fitted to various kinetic equations. The kinetic models included zero order, first order, Higuch model, and Korsmeyer-Peppas model.

\section{Zero order kinetics}

Drug dissolution from pharmaceutical dosage forms that do not disaggregate and release the drug slowly 


\section{Table 11: In vitro dissolution profile of AMOX Tablet layer (formulation A7-A12)}

\begin{tabular}{|c|c|c|c|c|c|c|}
\hline \multirow[t]{2}{*}{ Time (Hour) } & \multicolumn{6}{|c|}{$\%$ drug release in $0.1 \mathrm{~N} \mathrm{HCl}$} \\
\hline & A7 & A8 & A9 & A10 & A11 & A12 \\
\hline 0 & $0.00 \pm 00$ & $0.00 \pm 00$ & $0.00 \pm 00$ & $0.00 \pm 00$ & $0.00 \pm 00$ & $0.00 \pm 00$ \\
\hline 1 & $9.1 \pm 0.02$ & $8.6 \pm 0.04$ & $7.9 \pm 0.03$ & $12.8 \pm 0.04$ & $11.7 \pm 0.06$ & $12.1 \pm 0.07$ \\
\hline 2 & $13.4 \pm 0.03$ & $14.4 \pm 0.07$ & $14.5 \pm 0.05$ & $20.1 \pm 0.07$ & $17.5 \pm 9.03$ & $18.3 \pm 0.04$ \\
\hline 3 & $18.9 \pm 0.02$ & $20.3 \pm 0.03$ & $19.6 \pm 0.03$ & $27.2 \pm 0.02$ & $24.0 \pm 0.05$ & $25.7 \pm 0.05$ \\
\hline 4 & $24.2 \pm 0.04$ & 26. \pm 0.02 & 25. \pm 0.04 & $35.1 \pm 0.05$ & $29.7 \pm 0.05$ & $31.4 \pm 0.02$ \\
\hline 5 & $31.5 \pm 0.03$ & $32.8 \pm 0.04$ & $33.6 \pm 0.02$ & $43.0 \pm 0.03$ & $36.2 \pm 0.03$ & $37.8 \pm 0.06$ \\
\hline 6 & $38.7 \pm 0.05$ & $37.9 \pm 0.03$ & $38.2 \pm 0.05$ & $50.2 \pm 0.02$ & $42.1 \pm 0.02$ & $44.5 \pm 0.03$ \\
\hline 7 & $44.3 \pm 0.04$ & $45.2 \pm 0.06$ & $45.9 \pm 0.02$ & $57.7 \pm 0.05$ & $48.5 \pm 0.05$ & $50.6 \pm 0.04$ \\
\hline 8 & $51.2 \pm 0.02$ & $51.7 \pm 0.03$ & $52.1 \pm 0.03$ & $65.4 \pm 0.03$ & $55.2 \pm 0.04$ & $57.5 \pm 0.03$ \\
\hline 9 & $57.5 \pm 0.04$ & $58.0 \pm 0.04$ & $58.4 \pm 0.01$ & $72.7 \pm 0.02$ & $61.7 \pm 0.04$ & $64.2 \pm 0.05$ \\
\hline 10 & $63.4 \pm 0.05$ & $64.2 \pm 0.03$ & $64.5 \pm 0.05$ & $82.9 \pm 0.03$ & $68.9 \pm 0.0$ & $71.4 \pm 0.07$ \\
\hline
\end{tabular}

\section{Table 12: In vitro drug release profile of optimized bilayer tablet}

\begin{tabular}{|c|c|c|}
\hline \multirow{2}{*}{ Time } & \multicolumn{2}{|c|}{$\%$ drug release } \\
\cline { 2 - 3 } & Ranitidine Hydrochloride & $0.00 \pm 00$ \\
\hline 0 minute & $0.00 \pm 00$ & $0.00 \pm 00$ \\
\hline 5 minutes & $16.1 \pm 0.03$ & $0.00 \pm 00$ \\
\hline 10 minutes & $30.4 \pm 0.05$ & $0.00 \pm 00$ \\
\hline 15 minutes & $46.0 \pm 0.06$ & $0.00 \pm 00$ \\
\hline 2 minutes & $66.2 \pm 0.03$ & $0.00 \pm 00$ \\
\hline 25 minutes & $79.4 \pm 0.04$ & $11.3 \pm 0.06$ \\
\hline 3 minutes & $94.6 \pm 0.02$ & $13.1 \pm 0.04$ \\
\hline 1 hour & $96.1 \pm 0.02$ & $21.5 \pm 0.07$ \\
\hline 2 hours & $96.9 \pm 0.02$ & $32.6 \pm 0.02$ \\
\hline 3 hours & $96.9 \pm 0.02$ & $41.2 \pm 0.05$ \\
\hline 4 hours & $96.9 \pm 0.02$ & $52.4 \pm 0.03$ \\
\hline 5 hours & $96.9 \pm 0.02$ & $60.9 \pm 0.02$ \\
\hline 6 hours & $96.9 \pm 0.02$ & $68.3 \pm 0.05$ \\
\hline 7 hours & $96.9 \pm 0.02$ & $76.2 \pm 0.03$ \\
\hline 8 hours & $96.9 \pm 0.02$ & $83.4 \pm 0.02$ \\
\hline 9 hours & $96.9 \pm 0.02$ & $90.5 \pm 0.06$ \\
\hline 10 hours & $96.9 \pm 0.02$ & \\
\hline Where all values are mean \pm S.D. for $n=3$ & & \\
\hline & & \\
\hline
\end{tabular}

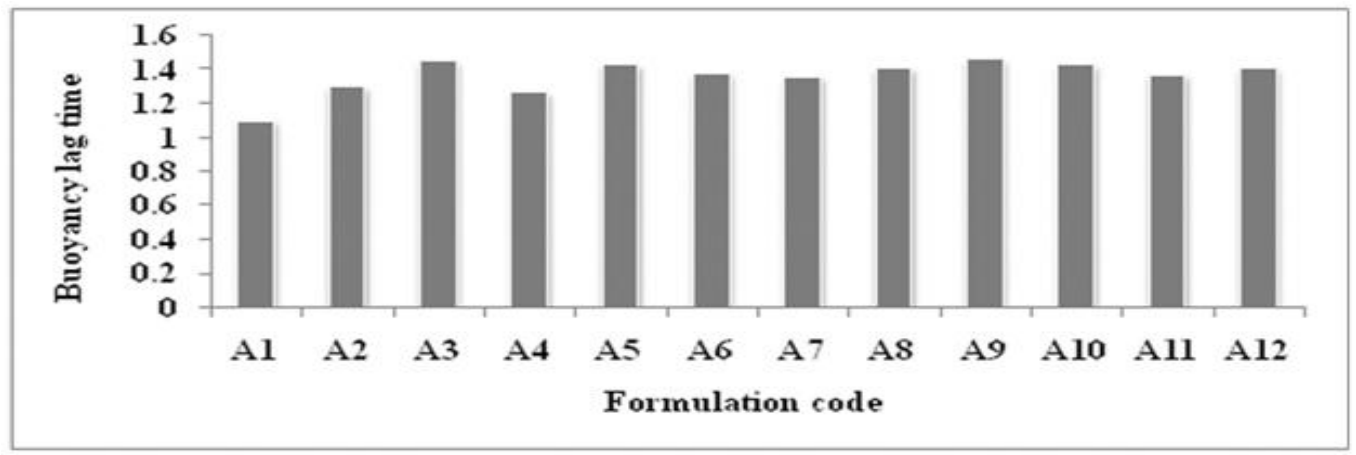

Figure 4: Buoyancy lag time of AMOX tablet layer 


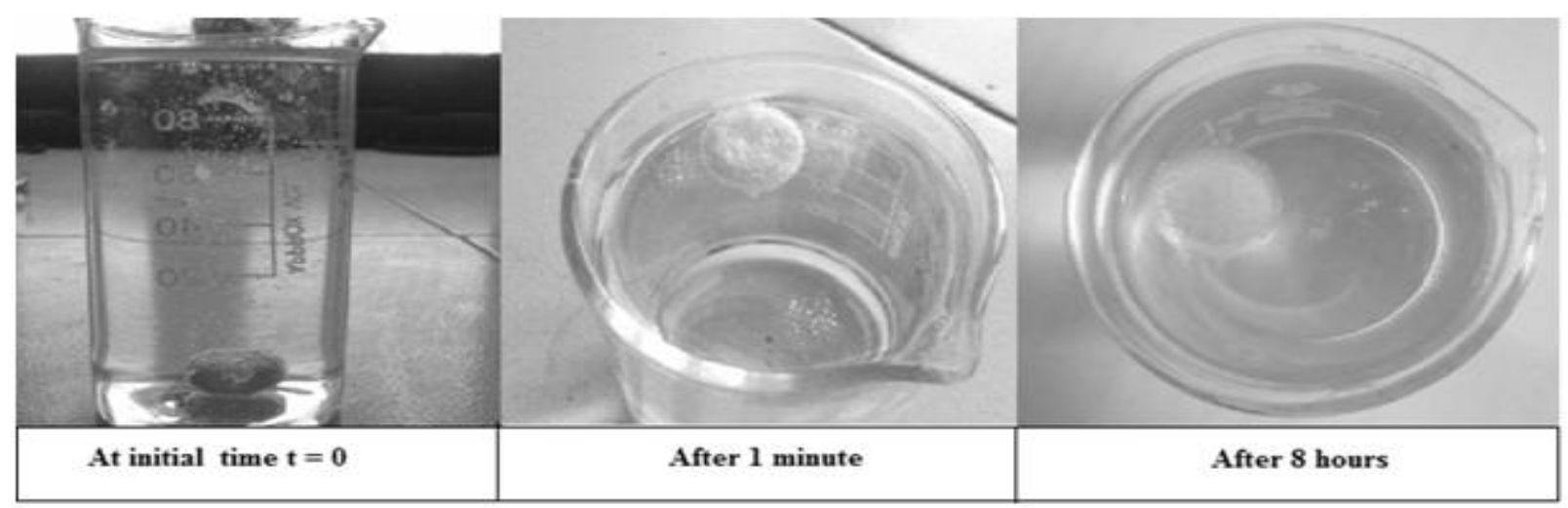

Figure 5: Buoyancy study at different time intervals

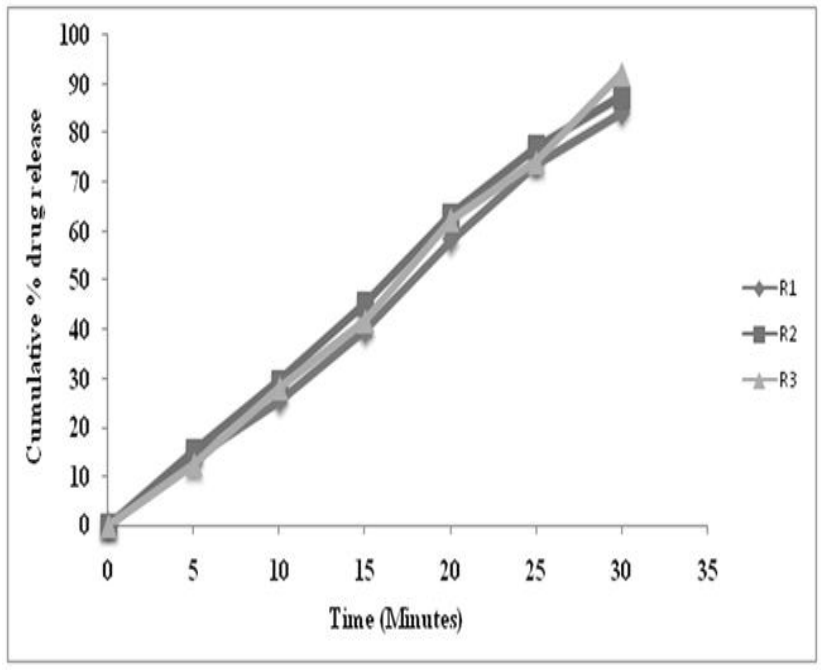

Figure 6: In vitro dissolution studies of tablet layers of RAN (R1-R3)

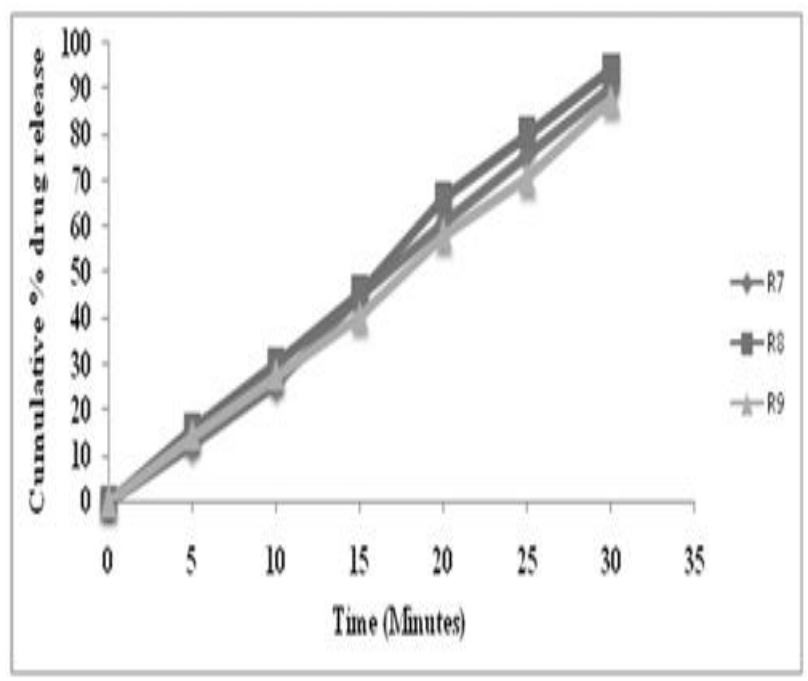

Figure 8: In vitro dissolution studies of tablet layers of RAN (R7-R9)

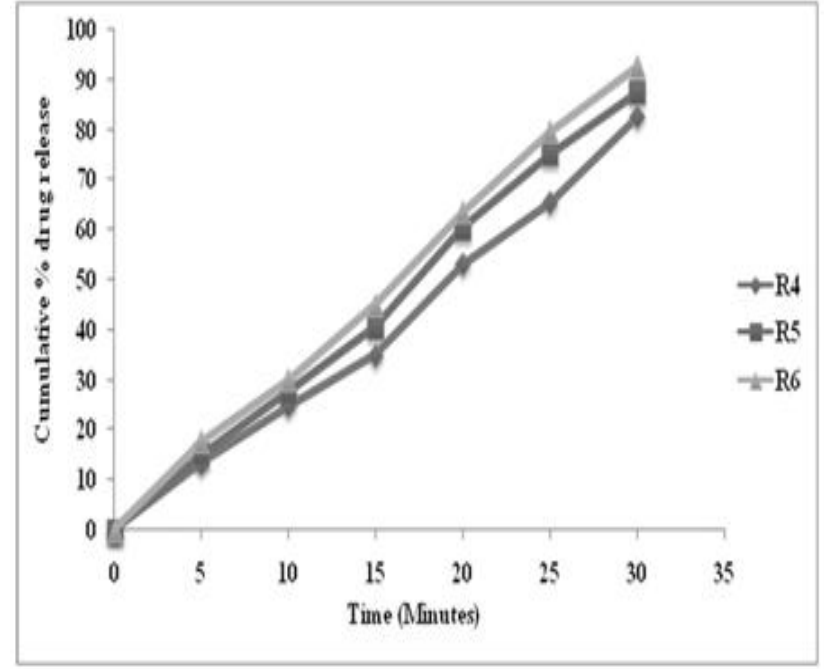

Figure 7: In vitro dissolution studies of tablet layers of RAN (R4-R6)

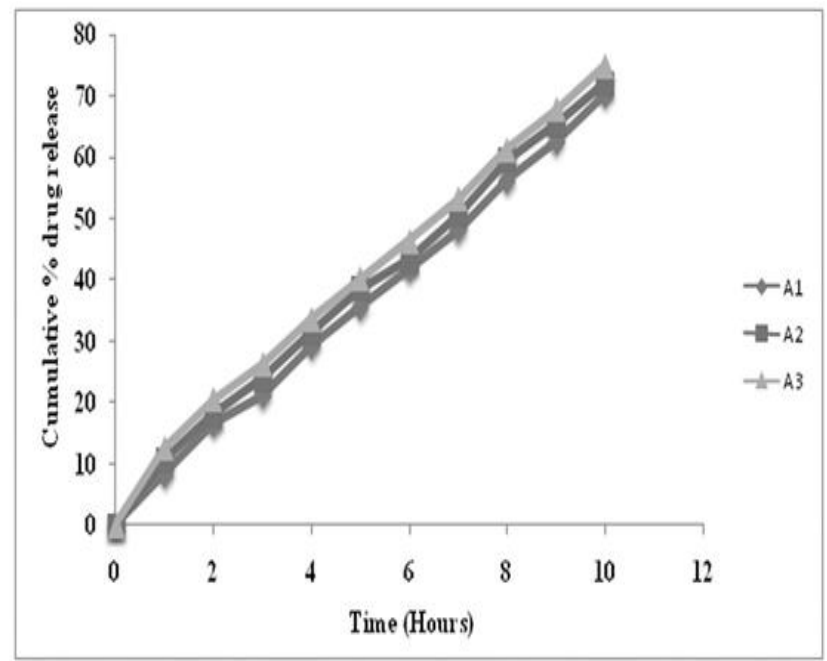

Figure 9: In vitro dissolution studies of tablet layers of AMOX (A1-A3) 


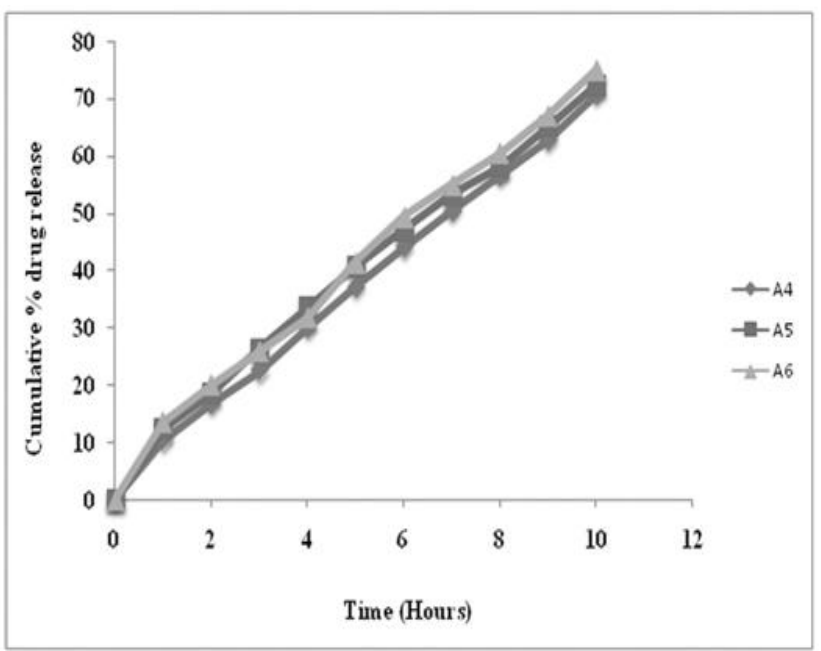

Figure 10: In vitro dissolution studies of tablet layers of AMOX (A4-A6)

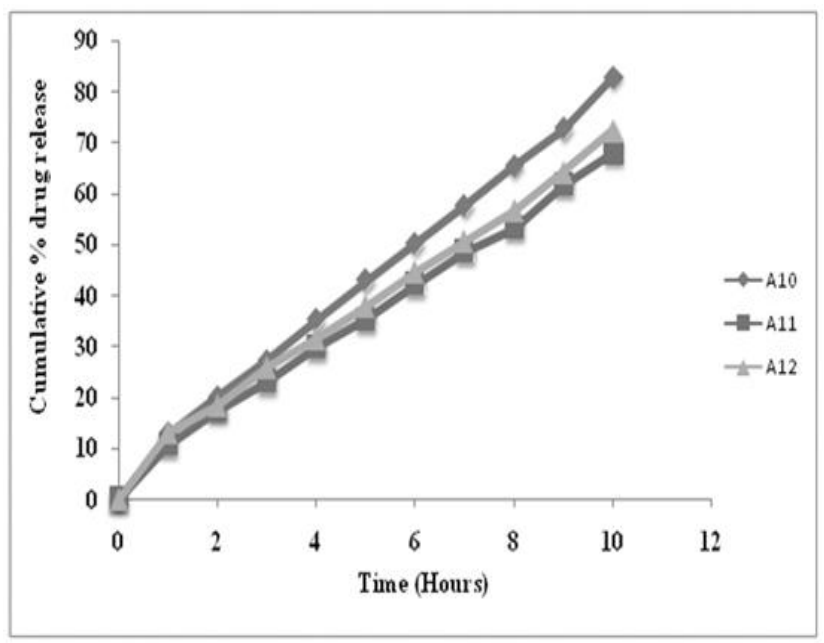

Figure 12: In vitro dissolution studies of tablet layers of AMOX (A10-A12)

(assuming that area does not change and no equilibrium conditions are obtained) can be represented by the following equation:

$$
\mathrm{Q}_{0}-\mathrm{Q}_{\mathrm{t}}=\mathrm{K}_{0} \mathrm{t}
$$

Where $\mathrm{Q}_{0}$ is the initial amount of drug in the pharmaceutical dosage form, $Q_{t}$ is the amount of drug in the pharmaceutical dosage form at time $\mathrm{t}$ and $\mathrm{k}$ is proportionately constant.

\section{First order kinetics}

The relation expressing this model

$$
\log C_{t}=\log C_{0}-K t / 2.303
$$

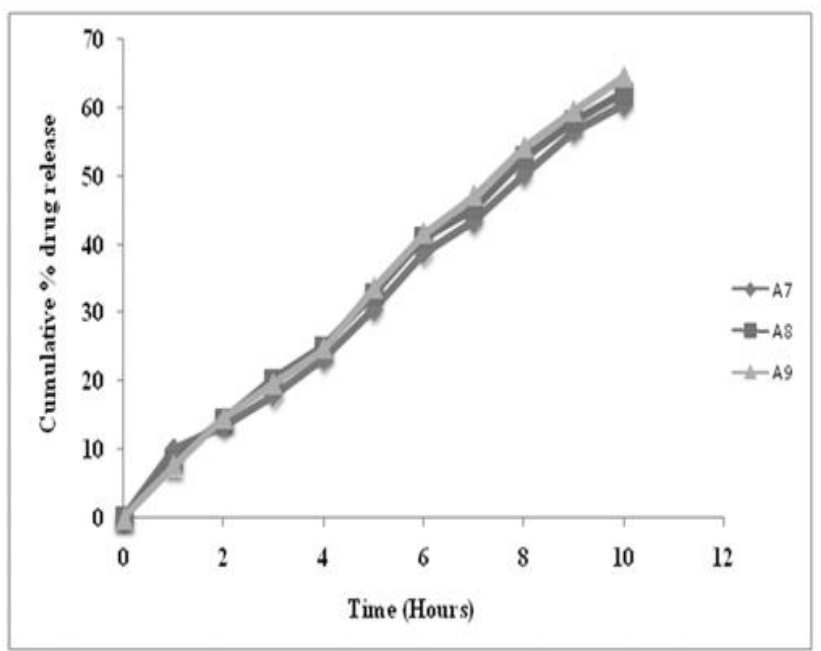

Figure 11: In vitro dissolution studies of tablet layers of AMOX (A7-A9)

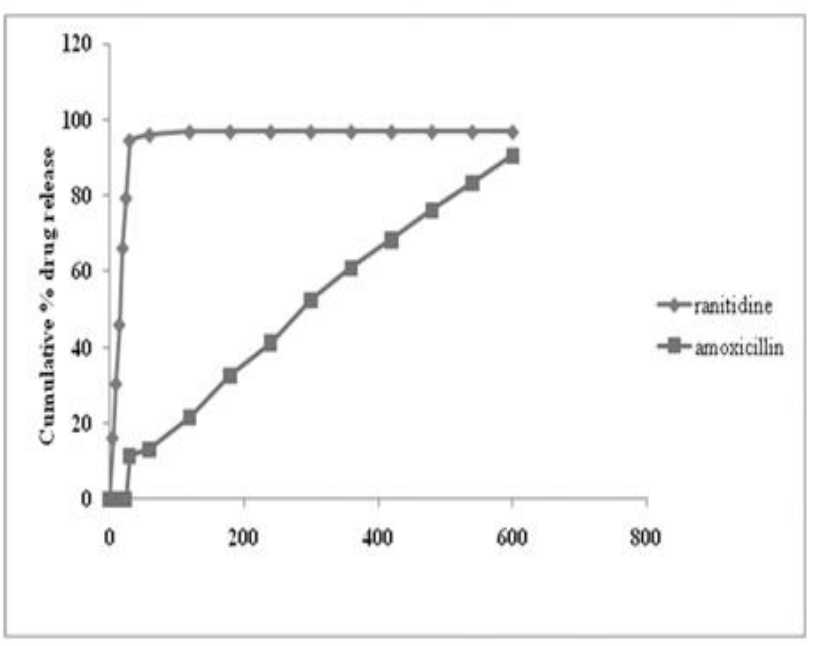

Figure 13: In vitro drug release profile of ranitidine hydrochloride and amoxicillin trihydrate from the bilayer tablet

Where $\mathrm{Ct}$ is the amount of drug released in time $\mathrm{t}, \mathbf{C}_{0}$ is initial amount of drug in the solution and $\mathrm{K}$ is the first order release rate constant.

\section{Korsmeyer Peppas model}

$\mathrm{K}$ is a constant incorporating structural and geometric characteristic of the drug dosage form and $\mathrm{n}$ is the release exponent, indicative of the drug release mechanism. For matrix tablets, an $\mathrm{n}$ value of 0.5 indicates diffusion controlled mechanism while an $n$ value of 1.0 indicates erosion controlled release. Intermediate values suggest dual mechanism of both diffusion and 


\section{Higuchi model}

It can be represented by the following equation

$$
\mathrm{Qt}=\mathrm{K}_{\mathrm{H}} \mathrm{t}^{1 / 2}
$$

Where Q $\mathrm{t}=$ the amount of drug released at time $\mathrm{t}$ and

$\mathrm{K}_{\mathrm{H}}=$ the Higuchi release rate

To determine the drug release mechanism, the in-vitro release data was fitted to various kinetic equations. The plots were drawn as per the following details.

- Cumulative percent drug released as a function of time (zero order kinetic plots).

- Log cumulative percent drug retained as a function of time (first order kinetics plots).

- Log cumulative percent drug released as a function of log time (Korsmeyer plots).

- Cumulative percent drug released versus square root of time (Higuchi plots).

The In-vitro release data of different kinetic models for Amoxicillin Trihydrate and Ranitidine Hydrochloride are shown in Table 13 and 14 respectively and release plots are presented in Figure 14-20.

\section{RESULT AND DISCUSSION}

Gastroretentive delivery system of Ranitidine Hydrochloride and Amoxicillin Trihydrate was prepared as bilayered tablets. The tablet is characterized by immediate release layer of Ranitidine Hydrochloride and gastroretentive layer of Amoxicillin Trihydrate. The study describes the formulation of both immediate and extended release drug for increased therapeutic efficacy and patient convenience.

Both tablet layers (RAN and AMOX) were optimized with the help of $3^{2}$ factorial design and experimental design respectively. The RAN tablet layer was optimized on the basis of following crucial factors like hardness, friability, disintegration time and drug content. The results were found to be 4.1, 4.5, 0.56, 0.465, 23, 22, 99.16, 98.89 for R8 and R9 batch respectively.

Similarly, the AMOX tablet layer was optimized on the basis of following crucial factors like hardness, friability,

\begin{tabular}{|c|c|c|c|c|c|c|c|}
\hline $\begin{array}{l}\text { Time } \\
\text { T hrs }\end{array}$ & $\begin{array}{c}\text { CDR(Q) } \\
\text { mg }\end{array}$ & $\sqrt{ } \boldsymbol{T}$ & $\log t$ & $\% Q$ & $\log \%$ Qr & $\begin{array}{l}\% \text { Drug } \\
\text { remained }\end{array}$ & $\log \% Q_{r}$ \\
\hline 0 hour & 0.00 & 0.00 & 0.00 & 0.00 & 0.00 & 100.00 & 2.00 \\
\hline 0.5 hour & 28.25 & 0.70 & 0.00 & 11.3 & 1.05 & 88.7 & 1.94 \\
\hline 1 hour & 32.75 & 1.00 & 0.00 & 13.1 & 1.11 & 86.9 & 1.93 \\
\hline 2 hour & 53.75 & 1.414 & 0.30 & 21.5 & 1.33 & 78.5 & 1.89 \\
\hline 3 hour & 81.5 & 1.73 & 0.44 & 32.6 & 1.51 & 67.4 & 1.82 \\
\hline 4 hour & 103.00 & 2.00 & 0.60 & 41.2 & 1.61 & 58.8 & 1.77 \\
\hline 5 hour & 131.00 & 2.23 & 0.70 & 52.4 & 1.72 & 47.6 & 1.67 \\
\hline 6 hour & 152.25 & 2.44 & 0.78 & 60.9 & 1.78 & 39.1 & 1.59 \\
\hline 7 hour & 170.75 & 2.64 & 0.85 & 68.3 & 1.83 & 31.7 & 1.50 \\
\hline 8 hour & 190.50 & 2.82 & 0.90 & 76.2 & 1.88 & 23.8 & 1.37 \\
\hline 9 hour & 208.50 & 3.00 & 0.95 & 83.4 & 1.92 & 16.6 & 1.22 \\
\hline 10 hour & 226.25 & 3.16 & 1.00 & 90.5 & 1.95 & 9.5 & 0.98 \\
\hline
\end{tabular}

\begin{tabular}{|c|c|c|c|c|c|c|c|}
\hline \multicolumn{7}{|c|}{ Table 14: Analysis of release kinetics for release of Ranitidine Hydrochloride } \\
\hline $\begin{array}{c}\text { Time T } \\
\text { (Minutes) }\end{array}$ & $\begin{array}{c}\text { CDR(Q) } \\
\mathbf{m g}\end{array}$ & $\sqrt{\mathbf{T}}$ & Log t & $\% \mathbf{Q}$ & Log \% Q & $\begin{array}{c}\% \text { Drug } \\
\text { remained }\end{array}$ & $\begin{array}{c}\text { Log \% } \mathbf{Q} \\
\mathbf{r}\end{array}$ \\
\hline 0 & 0.00 & $\mathbf{C}$ & 0.00 & 0.00 & 0 & 100 & 2 \\
\hline 5 & 16.1 & 2.23 & 0.7 & 16.1 & 1.2 & 83.9 & 1.92 \\
\hline 10 & 30.4 & 3.16 & 1 & 30.4 & 1.48 & 69.6 & 1.84 \\
\hline 15 & 46.0 & 3.87 & 1.17 & 46.0 & 1.66 & 54 & 1.73 \\
\hline 20 & 66.2 & 4.47 & 1.31 & 66.2 & 1.82 & 33.8 & 1.53 \\
\hline 25 & 79.4 & 5.0 & 1.39 & 79.4 & 1.9 & 20.6 & 1.31 \\
\hline 30 & 94.6 & 5.47 & 1.47 & 94.6 & 1.97 & 5.4 & 0.73 \\
\hline
\end{tabular}




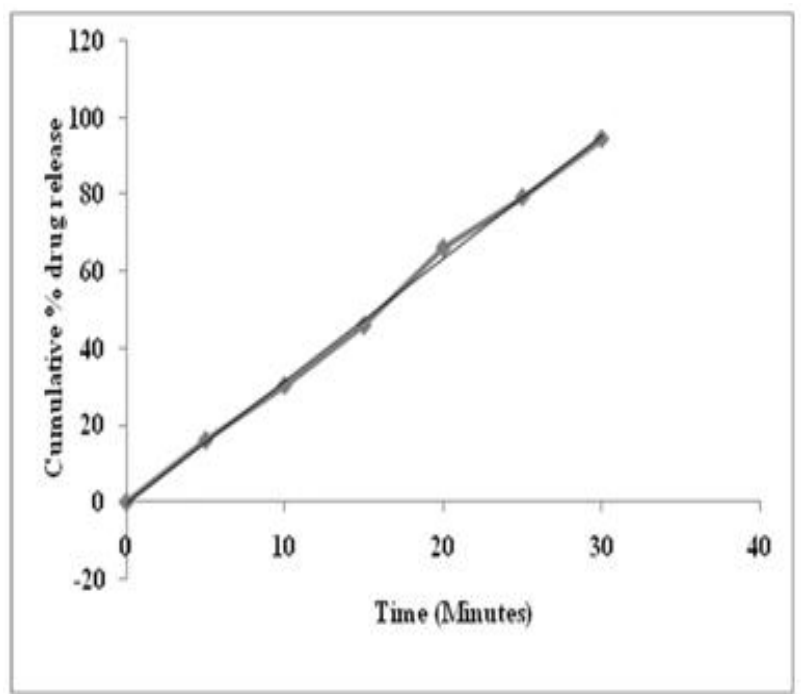

Figure 14: Zero order plot for drug release kinetics of ranitidine hydrochloride from the bilayer tablet

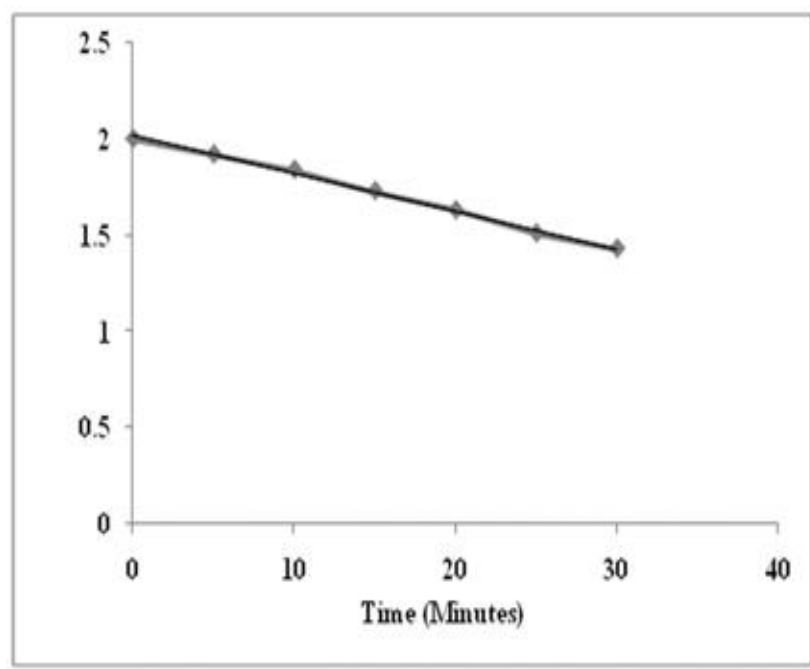

Figure 16: First order plot for drug release kinetics of ranitidine hydrochloride from the bilayer tablet

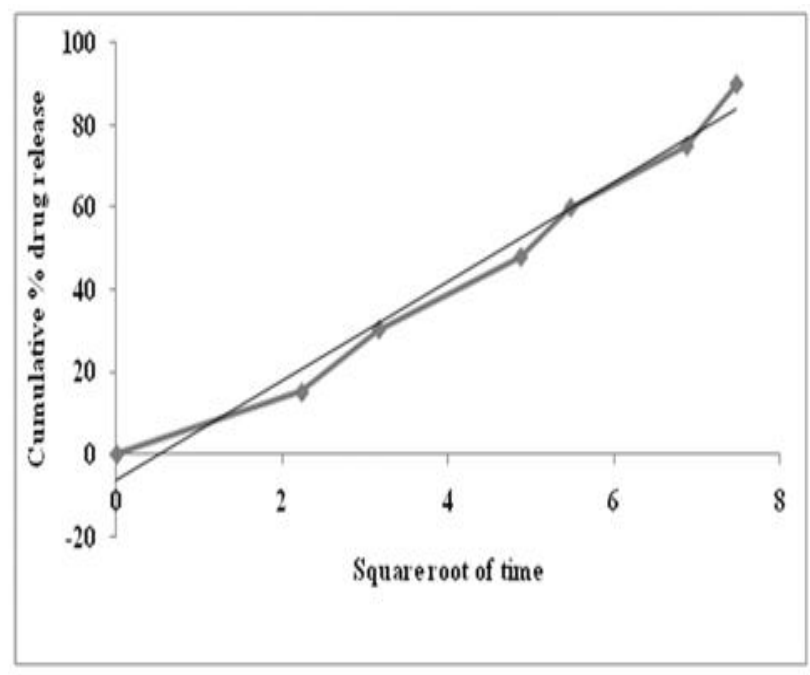

Figure 18: Higuchi's square root model for drug release kinetics of ranitidine hydrochloride from the bilayer tablet

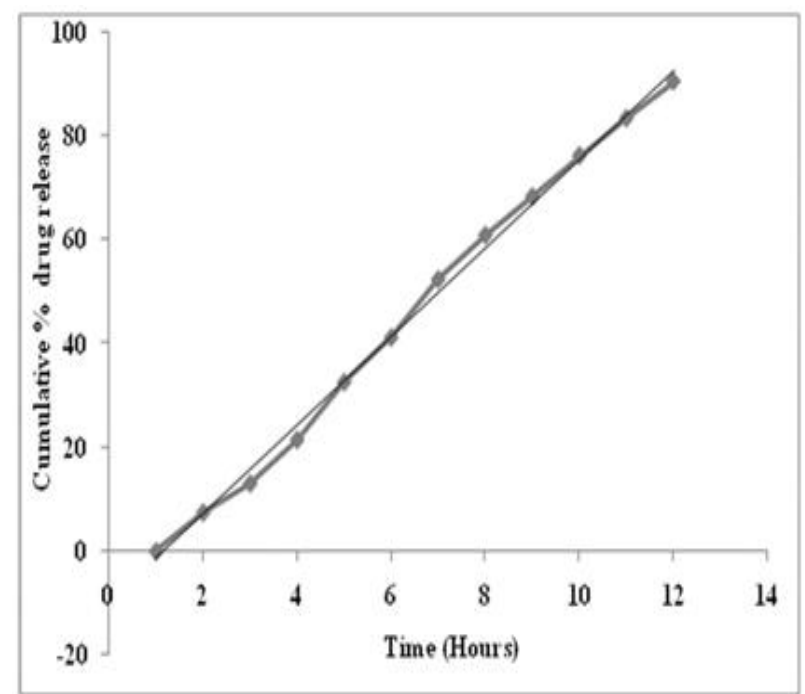

Figure 15: Zero order plot for drug release kinetics of amoxicillin trihydrate from the bilayer tablet

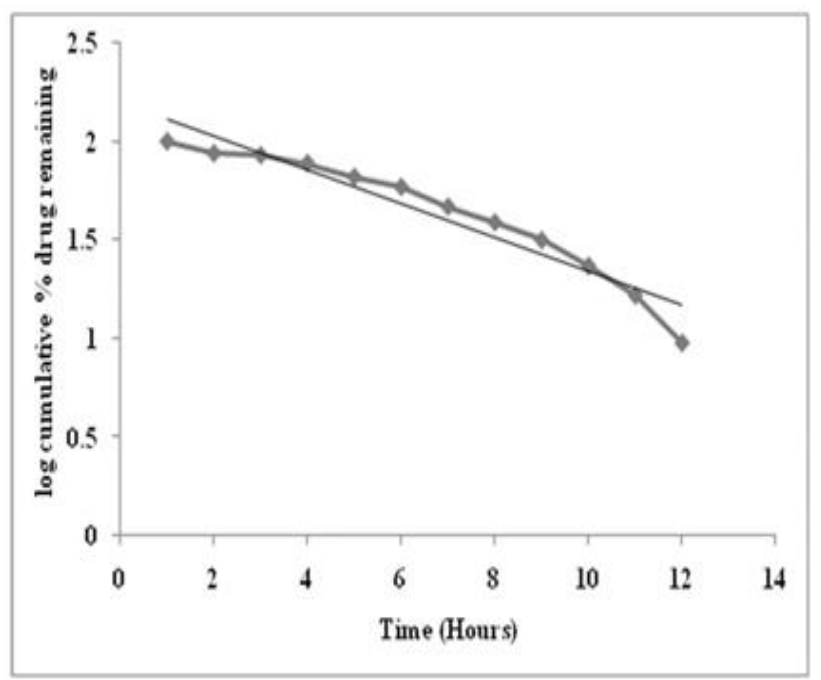

Figure 17: First order plot for drug release kinetics of amoxicillin trihydrate from the bilayer tablet

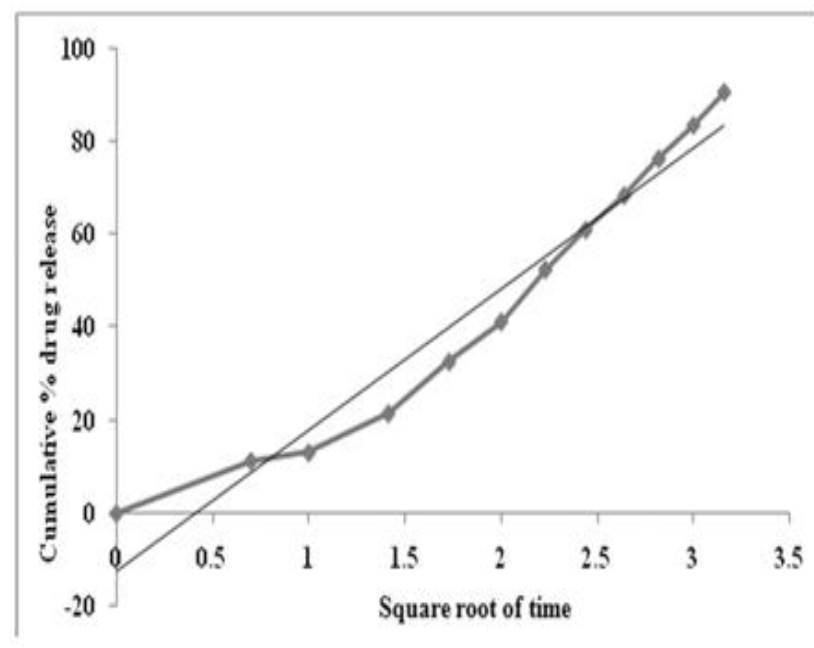

Figure 19: Higuchi's square root model for drug release kinetics of amoxicillin trihydrate from the bilayer tablet 


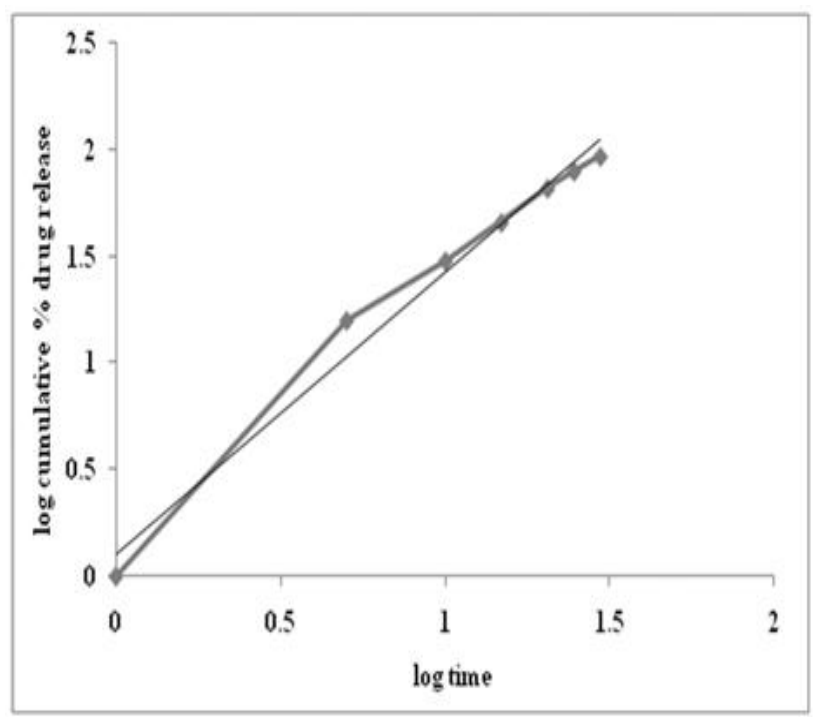

Figure 20: Korsmeyer Peppas double log plot model for drug release kinetics of ranitidine hydrochloride from the bilayer tablet

buoyancy lag time, duration of floating and drug content. The results were found to be 4.6, 4.2, 8.88, 0.91, $1.38,1.43,>8,>8,98.31,97.47$ for A6 and A10 batch respectively.

On the basis of above parameters, in case of RAN tablet layer, the formulation R8 and R9 were found to be best, but for further refinement both batches were subjected to dissolution studies in $0.1 \mathrm{~N} \mathrm{HCl}$ at $37 \pm 0.5^{\circ} \mathrm{C}$. On the basis of dissolution studies, the R8 was found to be superior amongst then which show $94.2 \%$ drug release in 30 minutes. Similarly, in case of AMOX layer, the formulation A6 and A10 were found to be best, but for further refinement both the batches were subjected to dissolution studies $0.1 \mathrm{~N} \mathrm{HCl}$ at $37 \pm 0.5^{\circ} \mathrm{C}$. On the basis of dissolution studies, the A10 was found to be superior amongst then which show $82.9 \%$ drug release in 10 hours.

From the above experiment, it was concluded that formulation layer R8 and formulation layer A10 were best for further development of Gastroretentive Bilayer tablet.

The results of the above experiment indicated that developed formulations R- 8 and A-10 are potential for-

Table 15: Correlation coefficient $\left(\mathrm{r}^{2}\right)$ for optimized formulation in different kinetic models

\begin{tabular}{|c|c|c|}
\hline \multirow{2}{*}{ Kinetic Model } & \multicolumn{2}{|c|}{ Co-relation coefficient $\left(\mathbf{r}^{2}\right)$} \\
\cline { 2 - 3 } & $\begin{array}{l}\text { Amoxicillin } \\
\text { Trihydrate }\end{array}$ & $\begin{array}{l}\text { Ranitidine } \\
\text { Hydrochloride }\end{array}$ \\
\hline Zero order & 0.996 & 0.998 \\
\hline First order & 0.923 & 0.999 \\
\hline Higuchi's square root model & 0.955 & 0.978 \\
\hline $\begin{array}{c}\text { Korsmeyer Peppas double } \\
\text { log plot model }\end{array}$ & 0.995 & 0.981 \\
\hline
\end{tabular}

mulation for preparation of Gastroretentive Bilayer tablet of Ranitidine Hydrochloride and amoxicillin.

\section{Micrometric study}

Bulk density, tapped density, compressibility index, Hausner's ratio and angle of repose of the powder blend were determined. The pre compressed parameters of the formulation were found to have satisfactory flow property.

\section{Physical Parameters}

The physical parameter viz hardness and friability of the compressed bilayer tablets were determined. The friability of the bilayer tablet formulation was found to be $0.642 \%$ which complies with the Pharmacopeial requirements. Hardness of the bilayer tablet formulation was satisfactory within the range of the $4.4 \pm 0.35$ $\mathrm{Kg} / \mathrm{cm}^{2}$ and it was sufficient to prevent the chipping and breaking during transportation.

\section{Floating character}

The bilayer tablet formulation remained buoyant for more than 8 hours with a floating lag time up to 1.5 minute. During the floating time, formulation maintained the matrix integrity. Floating duration and the floating lag time were found to be dependent on the amount of the polymers incorporated in the formulation and carbon dioxide generating excipients incorporated in the formulation.

\section{Drug content}

For the estimation of Ranitidine Hydrochloride and Amoxicillin Trihydrate in a bilayer tablet formulation, simultaneous estimation method was employed. The entire formulated tablet contained more than $90 \%$ of Ranitidine Hydrochloride as well as of Amoxicillin Trihydrate.

\section{Dissolution study of immediate layer}

In-vitro dissolution studies for the formulations were performed by USP-II type dissolution apparatus at 50 $\mathrm{rpm}$ in $900 \mathrm{ml} 0.1(\mathrm{~N}) \mathrm{HCl}$ medium (pH-1.2) at $37^{\circ} \mathrm{C}$. The release of the Ranitidine Hydrochloride from the immediate release layer was found to be $94.6 \pm 0.02 \%$ in 30 minutes. Use of crospovidone as super disintegrant found to optimum for the release of the immediate drug within 30 minutes with the disintegration time of $25 \pm 1.2$ seconds.

\section{Dissolution study of sustained release floating layer}

In-vitro dissolution studies for the formulations were performed by USP-II type dissolution apparatus at 50 $\mathrm{rpm}$ in $900 \mathrm{ml} 0.1 \mathrm{~N} \mathrm{HCl} \mathrm{pH}-1.2$ at $37^{\circ} \mathrm{C}$. The release of 
Amoxicillin Trihydrate for the sustained release floating layer was found to be $90.5 \pm 0.06 \%$ in 12 hours. The formulation remained buoyant for than 8 hours with buoyancy lag time of $1.57 \pm 0.83$ minutes.

\section{Release kinetics study}

The data obtained from In-vitro release were fitted into the model fitting analysis (Zero Order, Higuchi, First Order and Korsmeyer - Peppas Model). The interpretation of data was based on the values of the resulting regression co-efficient. The best fitted model for Amoxicillin Trihydrate and Ranitidine Hydrochloride was found to be zero order release model and first order release model respectively, with highest value of correlation coefficient of 0.996 and 0.999 respectively. Correlation coefficient (r2) for optimized formulation in different kinetic models are tabulated in table 15

\section{ACKNOWLEDGEMENTS}

Director, Mahakal Institute of Pharmaceutical Studies, Ujjain (M.P.)

\section{REFERENCES}

1. Joseph RR., Rhodes CT. Modern Pharmaceutics. 3rd edition, Marcel Dekker, Inc., New York. 1996; 58.
2. Tripathi KD. Essential of Medical Pharmacology. $6^{\text {th }}$ Edition, Jaypee Brother Medical Publishers (P) Ltd.; 2008. 628.

3. Khalil YI, Majeed SM. Formulation and Evaluation of Bialyer Matrix Tablets of Amoxicilin ans Esomeprazole as an Modified Oral Dosage Form for Treatment of Peptic Ulcer. International Journal of Pharmacy and Pharmaceutical Sciences. 2014; 6(3): 134-42.

4. Lachman L, Liberman HA, Kamig JL. The Theory and Practice of Industrial Pharamcy. $3^{\text {rd }}$ Edition , Varghese Publishing House. 1991; 430-56.

5. Indian Pharmacopoeia. New Delhi: Ministry of Health and Family Welfare, Government of India. Controller of Publication. 2007; 2; 770-1.

6. Sharma D, Singhai AK, Saraogi GK, Rajak A, Joshi D. Formulation and evaluation of Fast Dissolving Tablets of Ranitidine Hydrochloride using Different Superdisintegrant. International Research Journal of Pharmacy. 2011; 2(10):70-2.

7. Aslani A, Jahangiri H. Formulation, Characterization and Physicochemical Evaluation of Ranitidine Effervescent Tablets. Advanced Pharmaceutical Bulletin. 2013; 3(2): 315.

8. Dangi YS, Soni ML, Namdeo KP. A UV Spectrophotometric method developed for the simultaneous estimation of Amoxicillin Trihydrate and Ranitidine bismuth citrate for Helicobacter Pylori infections. Der Pharmacia Sinica. 2010; 1(3): 11-6.

9. Kumar PR, Doddayya H, Reddy SR, Bharath D, Uday KC. Investigative studies on novel floating tablets of clarithromycin for controlling Helicobacter pylori associated peptic ulcer disease. International Journal of Pharmaceutical Sciences Letters. 2012; 2(2): 44-8.

10. Yadav VT, Jayswal BD, Patel KN, Patel BA, Patel PA. Formulation and Evaluation of Floating Tablet of Amoxicillin Trihydrate. International Journal for Pharmaceutical Research Scholars. 2012; 1(2): 306-22.

11. Dash S, Murthy PN, Nath L, Chowdhary P, Kinetic Modelling on Drug Release from Controlled Drug Delivery Systems. Acta Poloniae Pharmaceutica n Drug Research. 2010; 67(3): 217-23. 